\title{
Strategic environmental assessment for the growth of Pietermaritzburg, South Africa
}

\author{
G. Nicolson \\ Department of Construction Economics, \\ University of Pretoria, South Africa
}

\begin{abstract}
This paper describes the processes and results of a Strategic Environmental Assessment study completed in February 2009 on how the expansion of the city of Pietermartizburg along its principal development axis should occur and be managed in an environmentally acceptable and appropriate manner. Pietermaritzburg is a city within the Province of KwaZulu-Natal of South Africa which is experiencing rapid growth due to a youthful population and significant rural to urban migration which is compounded by particular local circumstances. These are related to its recent designation as the capital city of the province of KwaZulu-Natal, its strategic location on a wider regional development axis, close proximity to a major metropolitan region, and the existing spatial distortions it has inherited in the "new South Africa" as a legacy of the previous apartheid-driven spatial planning ideology that was inflicted on this city.

A river catchment approach is selected as the most appropriate landscape and ecological unit within which to achieve the study's objectives. This study unit was based on the small Mkhondeni River catchment that was well located to serve this purpose. After a detailed investigation, public participation process and the formulation and application of an appropriate spatial planning conceptual framework the most desirable land use plan for this river catchment area has been proposed. The ecological linkages that should be maintained between this catchment and other neighbouring areas have also been identified, and the most appropriate environmental planning and management strategies to apply within the study area are recommended in order to ensure its sustainable development.
\end{abstract}

Keywords: city spatial planning, river catchment studies, environmental management, Pietermartizburg, South Africa. 


\section{Introduction}

Pietermartizburg is a relatively small city of approximately 750000 population about $90 \mathrm{~km}$ inland from the sub - tropical eastern coast of South Africa within Msunduzi Municipality in the Province of KwaZulu-Natal (fig. 1). The applied research that is reported on in this paper is a Strategic Environmental Assessment (SEA) completed in February 2009, within which the author was the principal consultant [1]. The study was jointly commissioned by the city's municipality and provincial environmental authorities, and was precipitated by a flurry of applications for substantial urban developments that were received by these authorities, all of which in various ways proposed extending the eastern urban edge of the city into areas that are currently open countryside.

The brief of the Strategic Environmental Assessment appointment was to answer the following questions, which are probably universal in city planning:

1. Are the received development applications a response to a real, organic need for growth of the city that can only be accommodated by its expansion into the surrounding countryside, or are they only artificial, speculative demands fuelled by property developers?

2. Is the resistance to these development proposals by certain local residents a reflection of valid environmental concerns, or is it based on a resistance to change and a smokescreen that is hiding other prejudices and fears?

3. Presuming that there is both a real need for an expansion of the urban edge, and that there are valid environmental concerns in the area of proposed expansion, how should this growth be planned and managed to ensure that it occurs in an environmentally acceptable and sustainable manner?

Although the research methodology that is applied in answering these questions will in many respects also be universal, it is required to be moulded to particular local circumstances. These local circumstances are described below within the context of addressing the first of the above questions. After this has been addressed, the questions to do with the nature of the receiving environment and the manner of permitting and managing appropriate urbanisation processes within it are dealt with.

\section{The need for urban expansion on the eastern urban edge}

In order to investigate and report on the whether there was a need for urban expansion on the eastern urban boundary of the city, a socio-economic report was commissioned from Dr. J. J. McCarthy [2], and the main findings and implications of his report are summarised below.

Pietermaritzburg is experiencing rapid growth due to the "normal" population growth pressures of a youthful population and significant rural-urban migration 
typical of most cities in the developing world. However, this growth is overlaid and compounded by the peculiar circumstances that prevail locally.

The province of KwaZulu-Natal is a new construct derived from the amalgamation of the "white" province of Natal and the previous apartheid Bantustan state of KwaZulu, which had its capital in the town Ulundi, in a region to the north know as Zululand. The recent decision to nominate Pietermartizburg as the province's capital city after a protracted period of uncertainty has unleashed certain development initiatives and has also led to the need to accommodate the influx of civil servants and their families from Ulundi.

A second impetus for growth of a more directional nature is due to Pietermartizburg being located inland from the metropolitan region of Durban to its east on the coast. Durban is a major manufacturing area of about 3.5 million population, which also has the busiest port in Africa (by goods value). Using the formula applied by urban geographers:

$$
\text { Lif }=f(P i . P j) / D i j
$$

where $L$ is the level of interaction (e.g. goods flow) between places $i$ and $j, P i$ and $P j$ are the populations of places $i$ and $j$, and Dij is the distance between $i$ and $j$, in the case of Durban and Pietermartizburg the derived energy is bound to create a high level of interaction between these to two centres, and tend to lead to their agglomeration over time along their main transport linkage between them, which is the N3 national highway.

This level of interaction is further augmented by the fact that the same N3 highway also serves as the main transport linkage between Durban and the continent's busiest economic node (as measured in GGP terms), which is the Johannesburg metropolitan area in the country's interior.

Thus, the national highway corridor route through Pietermartizburg, and in particular on its eastern side, inevitably emerges as the city's most economically potent axis by far. Notwithstanding that it lies along this axis, the distance from its eastern urban edge to the city hall in its urban centre is, counter intuitively, the shortest of its boundaries in comparison to the other points of the compass. In essence, urban expansion to the east appears to have been artificially truncated, due to the previous spatial planning approaches that have been imposed on the city, which are described below.

During the apartheid years, legislation controlled where the various races were permitted to reside. In Pietermartizburg this meant that Black people (the largest single group) were allocated to areas to the south, people of Indian descent to the north and the white population to the west and east, along the N3 highway. On the eastern side, it had been desirable for white people to live outside of the urban areas of Pietermartizburg in pleasant, lightly developed semi-rural areas, which are nevertheless conveniently closer to the city centre than would occur on the city's other boundaries.

With the abolition of the apartheid legislation in the 1990s there has occurred a "normalization" process, driven by market forces in which, especially more middle class Black and Indian families, migrated out of their historical areas into 
the more centrally located, previously white, areas, through an "urban filtering" process. The potential for this process to accommodate further growth is now limited, and there is tremendous pressure building up to expand the city's urban edge to accommodate demand. There are also certain economic pressures on the municipal authorities to expand the city to increase its rates base, which also makes the expansion of the city along this principal development axis opportune for them to support.

The question of need for urban expansion along the eastern boundary was therefore clearly answered in the affirmative. Indeed, all of the above indicates that the eastern urban settlement boundary is analogous to a dam wall, and thus the urban planning question is how these metaphorical "waters" that must soon be released should be guided in an environmentally acceptable and sustainable manner.

\section{The description and analysis of the study area}

\subsection{The selection of study area boundaries}

A river catchment based approach was applied as it was considered to be the ecological and landscape planning unit most suited to this study. The catchment area of a small tributary stream, the Mkhondeni River, $27 \mathrm{~km}^{2}$ in area and $10.5 \mathrm{~km}$ long, which conveniently drained in a south to north direction along the eastern urban edge of the city therefore became the principal area of focus within which spatial planning recommendations were made (fig. 1).

It was borne in mind whilst selecting this study unit that, although catchment areas do form convenient topographic units of study, there are always functional linkages and influences of both a biophysical and socioeconomic nature that extend well beyond their boundaries. There was therefore a nested hierarchy of focus applied within the study, with surrounding areas being investigated to the extent that their linkages and relationships with the central study area were influential in determining spatial planning proposals within it.

\subsection{Investigation of the study area}

\subsubsection{The biophysical characteristics}

Using the necessary specialists in their respective fields and computer based geographic information system (GIS) the information on the biophysical environment of the study area was compiled and mapped in regard to air quality, geology, slope, aspect, hydrology and wetlands. The initial investigation and mapping of vegetation cover and land uses was based on a locally developed tool for environmental planning, the Bioresource Programme which is explained and motivated by Camp [3]. This approach categorized the study area into Bioresource Groups, which in turn were further subdivided successively into their more detailed Bioresource and Ecological Units. The ecological units that were identified as having the highest conservation value were then identified and described in more detail. 


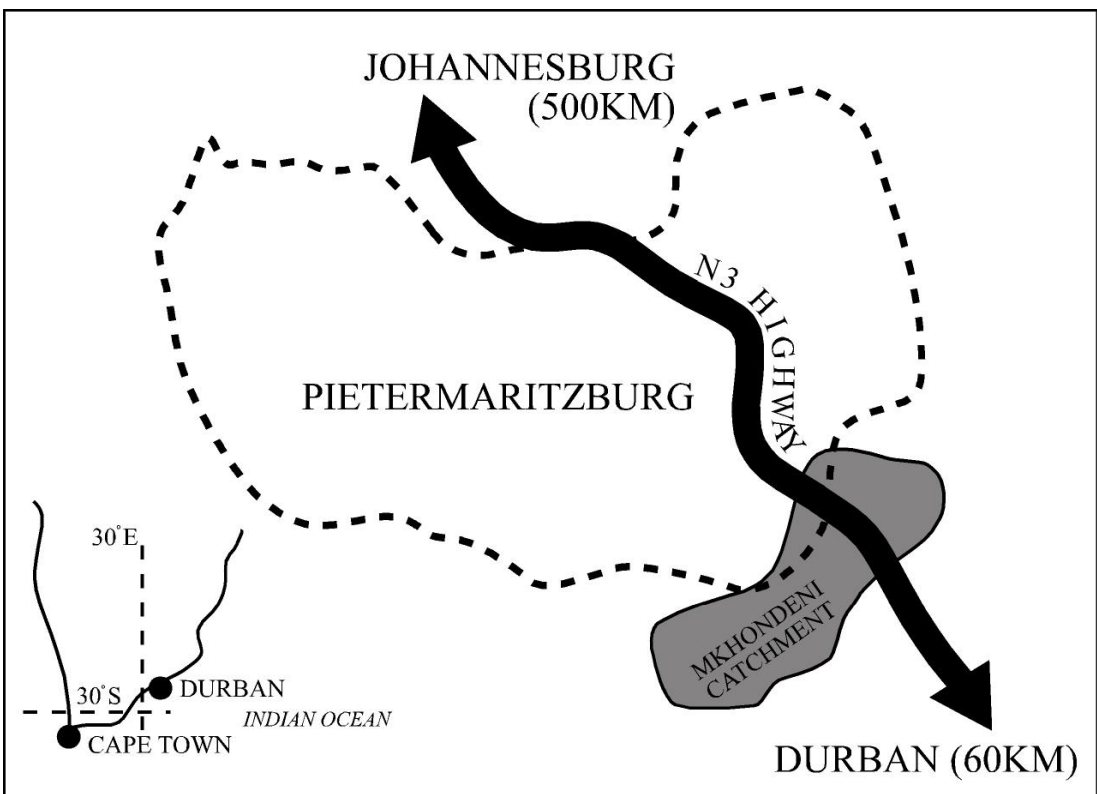

Figure 1: $\quad$ Study area location.

Following on from invited comments received on the draft SEA report by biodiversity specialists within the University of KwaZulu-Natal and the provincial conservation organisation, Ezemvelo KwaZulu-Natal Wildlife, certain further specialist studies were undertaken to increase the level of information and planning confidence in regard to biodiversity aspects. These studies were undertaken by recognized specialists on certain vegetation communities and their key plant species [4], butterflies [5], and the invertebrate groups of the millipedes (Diplopoda) molluscs (Mollusca) and earthworms (Annelida, Oligochaetae) [6].

The distribution of the particular butterfly group identified as being of concern (the Pierids) was known to be closely dependent on their caterpillar larvae host plant species (members of the Capparaceae). The need to investigate separately the nature and distribution of the other three invertebrate taxonomic groups was based on the knowledge derived from local research [7] that existing vegetation cover could not be used with complete confidence as a diagnostic tool, or surrogate, from which to infer which invertebrate fauna were likely to occur within a particular area.

\subsubsection{The aesthetic qualities}

The visual qualities of the study area were described and mapped in terms of the potential for development to create negative intrusions into those desired, attractive landscapes that provide a high level of visual amenity, and also any associated tourism and recreation values that may be associated with these qualities. 
The categorization of the landscape qualities and their associated outlooks was based on an approach first articulated by Appleton [8] that has been developed and applied locally by the author. Within this approach it is proposed that the most workable approach to identifying what is visually pleasing in a landscape is to develop a set of variables for perception based on a description of the situations in which landscapes create certain impressions on oneself, and probably humanity at large in the more general sense. These variables are:

Prospects and outlooks: Vantage point from which extensive views are obtained.

Refuges and enclosures: Locations within which a sense of privacy, seclusion and "getting away from it all" can be experienced.

Harmony and appropriateness: Landscapes are given a particular "visual character". In this particular study the areas were mapped in regard to the presence of one of the following visual characters:

- Wild Africa - Areas of natural vegetation of an African savannah and bushveld type nature.

- Farmed land - Where existing or past farming activities are the dominant visual influence.

- Settled countryside - Land that has a rural quality, but is well settled by people not actively farming, on smallholdings and large plots.

- Urban - Where the land has undergone transformation into dense urban settlement: Industrial, commercial or residential.

Features and symbols - Areas, features and structures, whether natural or built, which may have special symbolic significance or value were also mapped.

\subsubsection{The socioeconomic considerations}

The socioeconomic information relevant to the study was obtained from the study of McCarthy [2] and from the municipality and their own consultants on the existing supply or what was currently proposed for civil infrastructure (water supply, waste water disposal, electricity, transport, and schooling and other public amenities). Existing property boundaries and settlement patterns were also mapped.

The existing relevant planning policies and capacities of the municipality were also investigated. Special attention was paid to its existing environmental and open space planning policies and approaches and, in particular, its capacity to effectively manage open space areas within its jurisdiction.

The study's public participation process, which involved community representatives on its steering committee, newspaper advertisements, two public meetings and the wide circulation of the draft and final reports for comment, provided insights into the local community's attitudes and concerns.

\subsubsection{The relationships and potential linkages outside the catchment}

In order to not consider the catchment area in isolation and identify any significant relationships to areas outside of it that should be retained in the face 
of development, both the neighbouring catchment to the east of the Mkhondeni River and the adjacent areas of Pietermaritzburg were investigated and mapped at a level of resolution appropriate to the purposes of this study. Some significant linkages to these other areas that should be actively protected and retained in the face of development were identified in this process.

Within the context of this study, due to the generally steep topography of river valley sides, and the presence of floodlines and wetland areas along the valley floors, it was typically the intervening ridgelines between river catchments that get developed first. The linear developments along these intervening ridgelines between neighbouring catchments removed certain specific natural communities and also created obstacles to the movement of species between catchments.

\section{The main findings and their implications}

The processes of investigation, mapping and the specialist reports commissioned provided a substantial body of information. When collated and analysed with the aid of the GIS system, it was revealed that, if only the areas with the intrinsic qualities of steep slopes, floodlines, wetlands and areas of highest conservation value were excluded from development, this would permit approximately two thirds of the catchment area to be developed. The environmental resistance to developing the site due to these intrinsic qualities was therefore relatively limited, if one looked at it narrowly with what might be described as a "property developer's eye".

However, it was appreciated in the study that other planning considerations of a more strategic nature were also required to be taken into account. These were concerned with maintaining biologically sustainable and interlinked open spaces, landscape quality values and potential recreation and tourism opportunities. Moreover, there was also the objective set of planning urban open spaces to provide green relief in the face of the existing developmental trends which, when extrapolated, would lead ultimately to the fusing along the N3 highway of the cities of Durban and Pietermaritzburg into a single urban conurbation.

An additional consideration in making open space recommendations, was the recognized lack of capacity of the municipality, and also some of the landowners of larger properties, to effectively manage large areas of open space and prevent their degradation through such processes as alien species invasion, poaching and dumping. Alternative and more creative strategies which involved future and existing local landowners and affected communities in more effective environmental management activities was therefore needed, which could sometimes be in partnership with developers and/or the municipality.

A conceptual framework and general method of approach was formulated to reconcile the identified pressing development imperative with need to protect and enhance the intrinsic and strategic valuable environmental qualities that existed within the study area. 


\section{The theoretical basis and general method of approach to considering alternatives and proposing outcomes}

Within the study "the environment" was very broadly defined as the "Sum total of biophysical and socioeconomic processes occurring in time and space that affect the lives of individuals and communities". It was then considered more analytically from two perspectives. As both the total environmental quality, or milieu within which we live, and also the resource base which supports both human and other life forms on earth. The consideration of these two aspects of environmental quality and resource use was expanded on within this study. However, this paper focuses solely on its spatial planning aspects, as described further below.

An Open Space Planning Spatial model was formulated for the area that was based on long standing biogeographic theory [8] (fig. 2), and which has also been applied by the author within various projects over the years, based on earlier urban environmental planning work done on behalf of local provincial Town and Regional Planning Commission [9]. As illustrated in figure 3 overleaf, within this study the set of theoretical spatial planning principles illustrated in figure 2 below was applied to the planning of open space areas within and between river catchment drainage areas, where alternative $F$ in figure 3 is the most desirable one to apply wherever local circumstances permit.

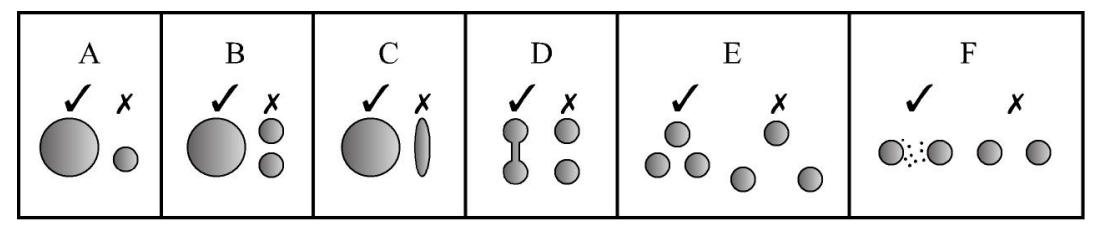

Figure 2: Biogeographic principles applied to open space planning.

\section{The proposed most desirable land uses}

Following on from the information acquired and an iterative planning process which included public participation, figure 4 illustrates the recommended most desirable land uses to apply within the Mkhondeni River catchment area, and table 1 which follows it provides a summary of the essential features of each proposed type of land use recommended as occurring within it.

In the most desirable land use plan the study area is divided into three types of land uses: Open Space; Conservation with Development; Normal Urban development. The general character, permitted land uses, the actual areas allocated, typical permitted densities and the environmental considerations that would apply to each type of land use are also indicated in table 1. 


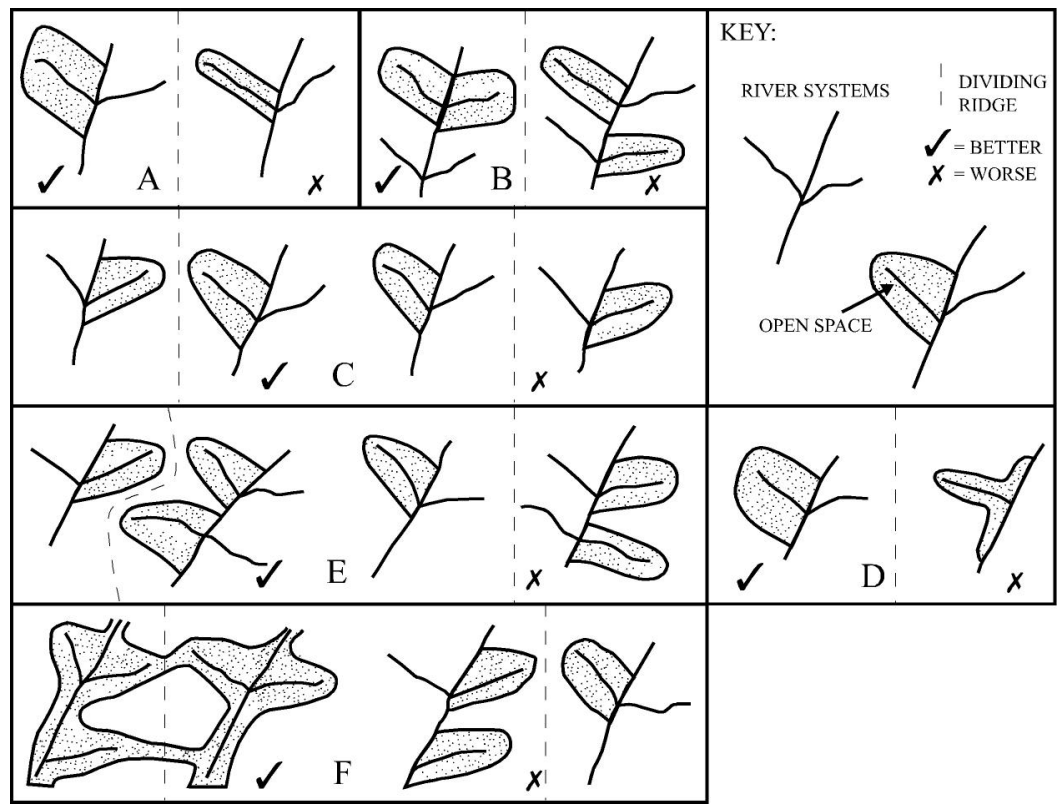

Figure 3: Open space planning principles applied to river catchments.

Guidelines were provided in the study to mitigate development's impacts on the environment for air quality, storm water management, water quality management, soil erosion, biological conservation and visual and other aesthetic impacts. Mitigation and development requirements concerned with traffic, schooling, crime, loss of quality of life, and how best use and manage open spaces, including involvement of the local community, were also provided.

\section{Overview of the outcomes of the study}

The Strategic Environmental Assessment reported on within this paper has successfully addressed the three key questions within its brief that are framed above within section 1, and did establish a broad environmental planning framework and planning tool for the relevant authorities to apply when considering development applications within the study area.

The study also provided useful information and approaches that could be integrated into the authorities' policies and plans for the wider environment that the study area was part of. The study also raised the level of informed debate and public participation as to what should be permitted or not within the affected areas amongst the affected stakeholders. 


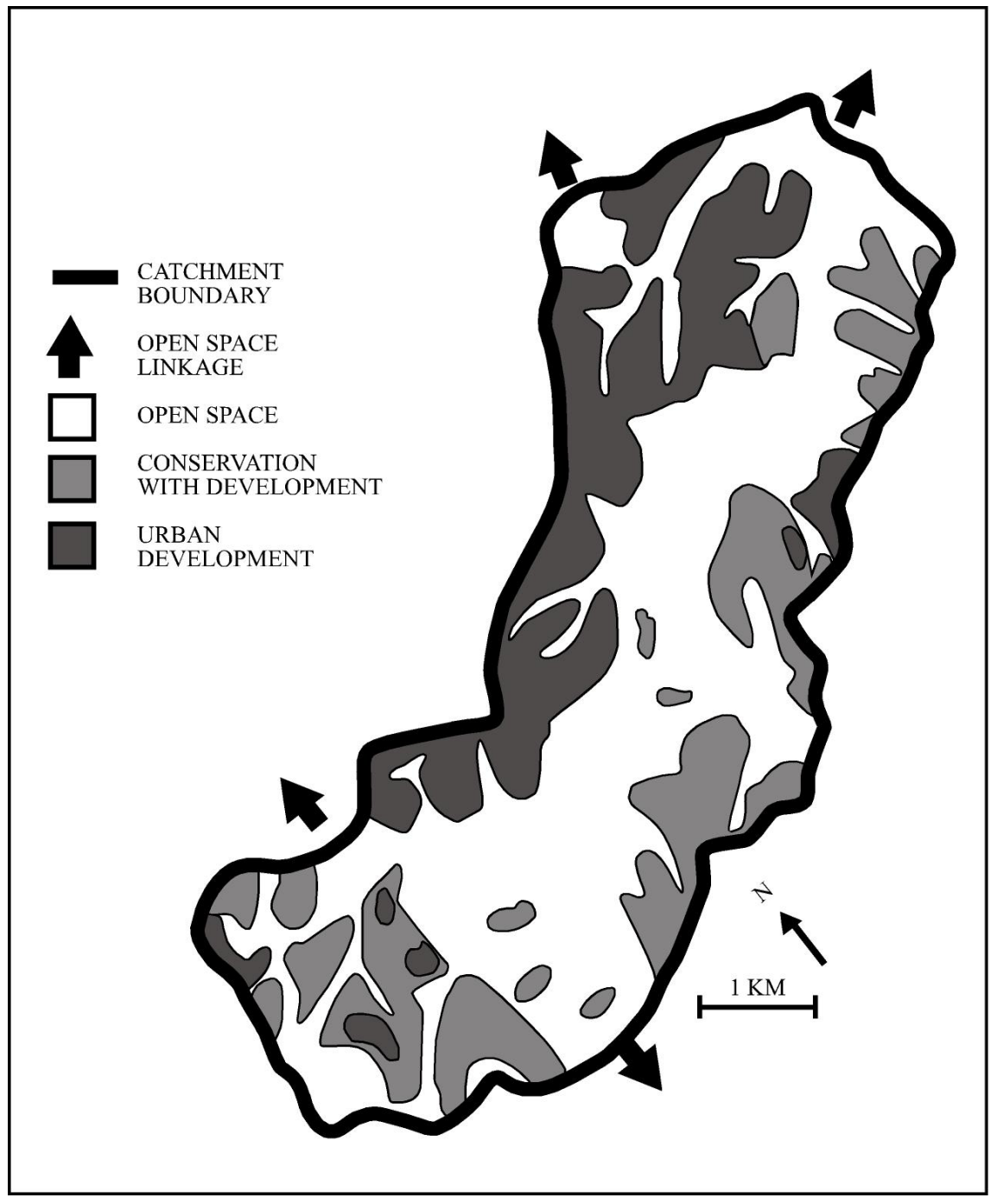

Figure 4: The most desirable land use plan. 
Table 1: $\quad$ The proposed land uses.

\begin{tabular}{|c|c|c|c|}
\hline & \multicolumn{3}{|c|}{ LAND USE } \\
\hline QUALITIES & OPEN SPACE & $\begin{array}{l}\text { CONSERVATION } \\
\text { WITH } \\
\text { DEVELOPMENT }\end{array}$ & $\begin{array}{l}\text { NORMAL } \\
\text { URBAN } \\
\text { DEVELOPMENT }\end{array}$ \\
\hline $\begin{array}{l}\text { General } \\
\text { character }\end{array}$ & $\begin{array}{l}\text { Kept open and } \\
\text { undeveloped, } \\
\text { rehabilitated } \\
\text { where necessary }\end{array}$ & $\begin{array}{l}\text { Low intensity } \\
\text { development, living } \\
\text { within, as opposed to } \\
\text { next to, nature in } \\
\text { Eco - estate and } \\
\text { ecotourism types of } \\
\text { developments. }\end{array}$ & $\begin{array}{l}\text { Urban development } \\
\text { similar in manner to } \\
\text { existing urban areas } \\
\text { within the city. }\end{array}$ \\
\hline $\begin{array}{l}\text { Permitted land } \\
\text { uses }\end{array}$ & $\begin{array}{l}\text { Open space } \\
\text { trails, public } \\
\text { facilities, } \\
\text { sometimes } \\
\text { agriculture and } \\
\text { game ranching. } \\
\text { May be both } \\
\text { public and } \\
\text { private. }\end{array}$ & $\begin{array}{l}\text { Developments within } \\
\text { open spaces, } \\
\text { focussed on } \\
\text { residential and } \\
\text { tourism uses. } \\
\text { Wherever possible } \\
\text { locally sustainable in } \\
\text { terms of own } \\
\text { infrastructure. }\end{array}$ & $\begin{array}{l}\text { Residential, } \\
\text { commercial and } \\
\text { industrial } \\
\text { developments } \\
\text { together with } \\
\text { municipal } \\
\text { infrastructure and } \\
\text { institutions }\end{array}$ \\
\hline Areas allocated & 1428 ha : $52 \%$ & 738 ha $: 27 \%$ & 564ha : $21 \%$ \\
\hline $\begin{array}{l}\text { Typical } \\
\text { permitted } \\
\text { densities }\end{array}$ & Not applicable & $\begin{array}{l}\text { Very low, depending } \\
\text { on circumstances, } \\
\text { typically not more } \\
\text { than } 2 \text { per hectare. }\end{array}$ & $\begin{array}{l}\text { Relatively high } \\
\text { densities, depending } \\
\text { on infrastructural and } \\
\text { other carrying } \\
\text { capacities. }\end{array}$ \\
\hline $\begin{array}{l}\text { Environmental } \\
\text { considerations } \\
\text { that will apply }\end{array}$ & $\begin{array}{l}\text { Many areas will } \\
\text { require } \\
\text { rehabilitation, } \\
\text { and ongoing } \\
\text { management } \\
\text { funding and } \\
\text { institutional } \\
\text { arrangements, } \\
\text { depending on } \\
\text { local } \\
\text { arrangements } \\
\text { and } \\
\text { circumstances. }\end{array}$ & $\begin{array}{l}\text { Detailed planning of } \\
\text { developments } \\
\text { required to protect } \\
\text { and enhance existing } \\
\text { biodiversity and other } \\
\text { resources. Land use } \\
\text { often very } \\
\text { complementary to } \\
\text { adjacent open spaces. } \\
\text { Wherever possible no } \\
\text { internal fences and } \\
\text { other forms of } \\
\text { interlinking } \\
\text { encouraged. }\end{array}$ & $\begin{array}{l}\text { Associated with } \\
\text { major land } \\
\text { transformations and } \\
\text { loss of existing land } \\
\text { cover. Special } \\
\text { measures often } \\
\text { required to off site } \\
\text { implications in regard } \\
\text { to such impacts as } \\
\text { storm water } \\
\text { management, soil } \\
\text { erosion, traffic } \\
\text { congestion and } \\
\text { pollution }\end{array}$ \\
\hline
\end{tabular}

\section{References}

[1] Nicolson G., Strategic Environmental Assessment of the Mkhondeni Stream catchment area within the Msunduzi Local Municipality of 
KwaZulu-Natal, 6 Indwa Place, Kloof 3610, South Africa guyn@saol.com, 2009.

[2] McCarthy, J.J., Msunduzi East-Socio Economic Report (Appendix 1), Strategic Environmental Assessment of the Mkhondeni Stream catchment area within the Msunduzil Municipality of KwaZulu-Natal, in Nicolson [1]

[3] Camp, K., The role of the bioresource programme in environmental planning (Appendix 3), Strategic Environmental Assessment of the Mkhondeni Stream catchment area within the Msunduzi Local Municipality of KwaZulu-Natal, in Nicolson [1]

[4] Granger, J.E., A comparative reconnaissance level assessment the conservation value of selected areas of grassland and wooded grassland occurring on the property known as Elephant Hills, Bellevue, Pietermartizburg (Appendix 6) in Nicolson [1] Strategic Environmental Assessment of the Mkhondeni Stream catchment area within the Msunduzi Local Municipality of KwaZulu-Natal, in Nicolson [1]

[5] Bonkewitzz, A.N., Butterfly and host plant assessment of the Mkhondeni catchment area (Appendix 8) Strategic Environmental Assessment of the Mkhondeni Stream catchment area within the Msunduzi Local Municipality of KwaZulu-Natal, in Nicolson [1]

[6] Hamer, M., Specialist report on the millipedes, molluscs and earthworms of the Mkhondeni Stream catchment area (Appendix 7), Strategic Environmental Assessment of the Mkhondeni Stream catchment area within the Msunduzi Local Municipality of KwaZulu-Natal, in Nicolson [1]

[7] Slotow, R., Personal communication. 19 October 2006. School of Biological \& Conservation Sciences, University of KwaZulu-Natal.

[8] Appleton J. The Experience of Landscape John Wiley \& Sons, 1984.

[9] Diamond J.M. The island dilemma: Lessons of modern biogeographic studies for the design of natural areas. Biological Conservation Vol 7 (2) pp $129-145,1975$.

[10] Nicolson, G., Towards a plan for the Durban Metropolitan Open Space System, Natal Town \& Regional Planning Commission Report, 70, Private Bag X9038 Pietermaritzburg 3200 South Africa, 1987. 